Vol. 1, No. 2, Desember 2020

\section{SPEKTA}

Jurnal Pengabdian Kepada Masyarakat : Teknologi dan Aplikasi

Journal homepage :

http://journal2.uad.ac.id/index.php/spekta

\title{
PERANCANGAN SCIENCE CORNER (SCI-CO) SEBAGAI MEDIA BANTU VISUAL IMAGE BAGI GURU TK PGRI PALATTAE
}

\author{
Adji Syaifullah", ${ }^{1, *}$ Andi Muhamad Iqbal Akbar Asfar', Andi Muhammad Irfan Taufan \\ Asfar $^{3}$, A Nurannisa F.A ${ }^{3}$, Marlina ${ }^{3}$, Sitti Nurjannah ${ }^{1}$ \\ ${ }^{1}$ Program Studi Teknologi Pendidikan, STKIP Muhammadiyah Bone, Watampone, Sulawesi Selatan, Indonesia \\ ${ }^{2}$ Program Studi Teknik Kimia, Politeknik Negeri Ujung Pandang, Makassar, Sulawesi Selatan, Indonesia \\ ${ }^{3}$ Program Studi Pendidikan Matematika, STKIP Muhammadiyah Bone, Watampone, Sulawesi Selatan, Indonesia
}

\section{INFO ARTIKEL}

Diterima: 14 September, 2020

Direvisi: 6 Oktober, 2020

Disetujui: 19 Oktober, 2020

Keywords:

Science Corner;

Visual Image;

Science for Child.

\begin{tabular}{l}
\hline ABSTRACT \\
\hline Science learning is one of the most important lessons \\
taught to children from an early age, especially in \\
kindergarten. Learning is directed towards creative and \\
critical thinking that is able to direct children's high \\
order thinking skills. The community service program \\
with the PKM-M scheme was carried out at TK PGRI, \\
Palattae Village, Bone Regency regarding the problems \\
of teachers as partners in teaching science in the \\
classroom to make it easier and more interactive through \\
the design of a science corner (Sci-Co). This service was \\
carried out in three main stages, namely counseling, \\
design, and dissemination of the Sci-Co design. Learning \\
using Sci-Co will be able to make children more critical \\
and able to analyze events or phenomena that are often \\
encountered in a child's environment, such as rain. Even \\
though this program is conducted online, it is able to \\
build teachers' skills in presenting Sci-Co in a simple \\
way, the result of the teacher's own creativity with less \\
than one week of processing time at the same time the \\
teacher claims that this Sci-Co will help him \\
accommodate children's knowledge in learning so that it \\
is more meaningful less than one hour.
\end{tabular}

\section{PENDAHULUAN}

Media adalah sebuah perantara penyampaian pesan antara penerima dan sumber yang dapat membantu mencapai tujuan yang diinginkan. Media dalam bidang pendidikan merupakan salah satu kunci pencapaian keberhasilan guru dalam mencapai tujuan pembelajaran. Akan tetapi, keterbatasan media menjadi salah satu penyebab rendahnya kualitas belajar (Mahnu, 2017). Rendahnya kualitas belajar akan berdampak pada kemampuan murid dalam memahami pengetahuan yang dipelajarinya sebab tidak adanya

\footnotetext{
* Corresponding author.

E-mail address: ajisaifullah559@gmail.com

https://doi.org/10.12928/spekta.v1i2.2791
} 
stimulus kognitif melalui penggunaan indera dalam belajar yang mampu meretensi memori siswa dalam mengenal topik bahasan yang ditransfer oleh guru. Beberapa penyebab guru enggan menggunakan alat bantu peraga disebabkan oleh paradigma guru menganggap bahwa alat peraga bantu merupakan barang canggih, guru tidak memiliki keterampilan membuat media, guru nyaman menggunakan metode ceramah, dan media tidak tersedia (Tafonao, 2018).

Pembelajaran saat ini diarahkan pada kemampuan berpikir kritis dengan mengintegrasikan pembelajaran ke arah high order thinking menggunakan pendekatan tematik integratif dan pendekatan saintifik (Sutama dkk, 2020). Proses berpikir kritis akan lebih jika sedari dini diajarkan kepada anak terlebih lagi pada tingkat taman kanak-kanak. Anak-anak pada usia tersebut berada pada usia golden age, dimana murid sedang banyak menggunakan imajinasi dan daya kreasinya dalam belajar serta pada saat inilah anak diarahkan ke arah aktifitas berpikir dengan menggunakan otak kiri (berpikir kritis) dan otak kanan (berpikir kreatif) (Musrikah, 2018). Pembelajaran sains semakin berkembang terfokus pada perkembangan kognitif anak usia dini sehingga sedari dini pembekalan sains menjadi penting (Roza, 2012). Metode-metode yang dapat digunakan dalam meningkatan kemampuan sains adalah sesuatu yang mampu mengajak anak untuk berpikir, menalar, mampu menarik kesimpulan, dan membuat generalisasi yaitu dengan cara anak mampu memahami lingkungan di sekitarnya (Saepuddin, 2011). Oleh karena itu, diperlukan suatu perancangan media bantu yang menarik untuk mengakomodasi hal ini dengan menggabungkan media audio dan visual image (mono image) yang interaktif.

Media sebagai alat bantu didesain untuk dapat memicu stimulasi motorik murid, pengembangan sisi kognitif dan pengembangan afeksinya. Salah satu media yang akan menarik minat murid dalam belajar adalah media yang berbasis pada visual image. Pelajaran berbasis visual image merupakan metode pembelajaran yang menggunakan gambar dan suara, sehingga mampu meningkatkan daya tarik murid untuk membaca dan menstimulus pikirannya supaya lebih berfikir secara kritis dan kognitif serta meningkatkan kreativitas anak usia dini. Beberapa penelitian mengungkapkan bahwa warna pada gambar mampu meningkatkan kinerja short term memory dan dapat menjadi salah satu strategi alternatif dalam penyajian materi yang mampu meningkatkan kemampuan kognitif serta hasil belajar murid yang pada akhirnya murid mampu melakukan refleksi dari apa yang dipelajarinya (Abidah dkk, 2019; Sulastri, 2016; Azis dkk, 2019). Media visual image ini akan mengarah kepada pembelajaran sains secara kontekstual yang mana pembelajaran ini, guru mampu mengintegrasikan apa yang dipelajari murid dengan kehidupan nyata, sehingga belajar akan lebih mudah diserap oleh murid (Hartoyo, 2009).

Pemilihan materi sains dikarenakan murid dalam kesehariannya sering menjumpai fenomena alam yang secara otentik mudah diingat dan dipahaminya. Fenomena alam yang paling sering djumpai dan akan dikemas lebih menarik berbasis visual image adalah proses terjadinya hujan, proses terjadinya pelangi, dan beberapa proses lainnya. Pembuatan media visual image akan ditempatkan pada salah satu tempat yang disebut sebagai Sci-Co (Science Corner) atau pojok sains. Sci-Co merupakan tempat yang mudah diakses oleh murid untuk belajar mengenai proses-proses alam, sehingga akan merangsang proses berpikir murid untuk lebih kritis dan mampu menganalisis.

Sci-Co atau pojok sains akan menjadi tempat anak mengenal teknologi yang dikemas dengan visual image interaktif. Melalui penerapan Sci-Co, maka akan merangsang cara berpikir murid sekaligus menstimulasi kemampuan motorik dan afektif yang dimilikinya. Murid akan lebih mampu mengingat informasi-informasi yang 
Vol. 1, No. 1, Desember 2020

disampaikan sebab ingatan atau memori pada awalnya dikodekan hingga dilakukan retrieval, sehingga dapat menjadi suatu ingatan jangka panjang (long term memory) (Sujarwo dan Okatviana, 2017). Melalui Sci-Co, guru akan lebih peka dalam mengupdate pengetahuan yang dimilikinya dalam mengembangkan proses berpikir kritis dan analisis murid. Oleh karena itu, pemanfaatan pojok sains atau Sci-Co akan menjadi harapan para Guru TK khususnya di TK PGRI Kelurahan Palattae dengan lebih mudah mengajarkan sains sekaligus mampu menumbuhkembangkan kemampun berpikir anak yang mampu kritis dan analisis, sehingga tujuan Pendidikan Anak Usia Dini (PAUD) dapat terwujud melalui pengembangan ranah pendidikan (kognitif, afektif, dan psikomotorik) murid yang dapat terbangun dari pondasi dasar yang kuat yaitu di Taman Kanak Kanak. Selain itu, TK PGRI Kelurahan Palattae akan menjadi TK percontohan dalam proses belajar murid dan akan mampu memperkenalkan Sci-Co sebagai produk unggulan dari TK PGRI Kelurahan Palattae dalam mengembangkan proses berpikir murid khususnya dalam belajar sains.

\section{METODE PELAKSANAAN}

Pelaksanaan pengabdian ini didasarkan pada skema PKM-M yang merupakan suatu program kreativitas mahasiswa dalam bentuk pengabdian kepada masyarakat yang berfokus pada permasalahan mitra. Adapun mitra yang difokuskan pada pelaksanaan pengabdian ini adalah guru TK PGRI Kelurahan Palattae Kecamatan Kahu Kabupaten Bone Propinsi Sulawesi Selatan yang berjumlah 3 orang termasuk kepala sekolah. Pelaksanaan PKM-M ini dilaksanakan sepenuhnya secara virtual dengan diagram alir sebagai berikut.

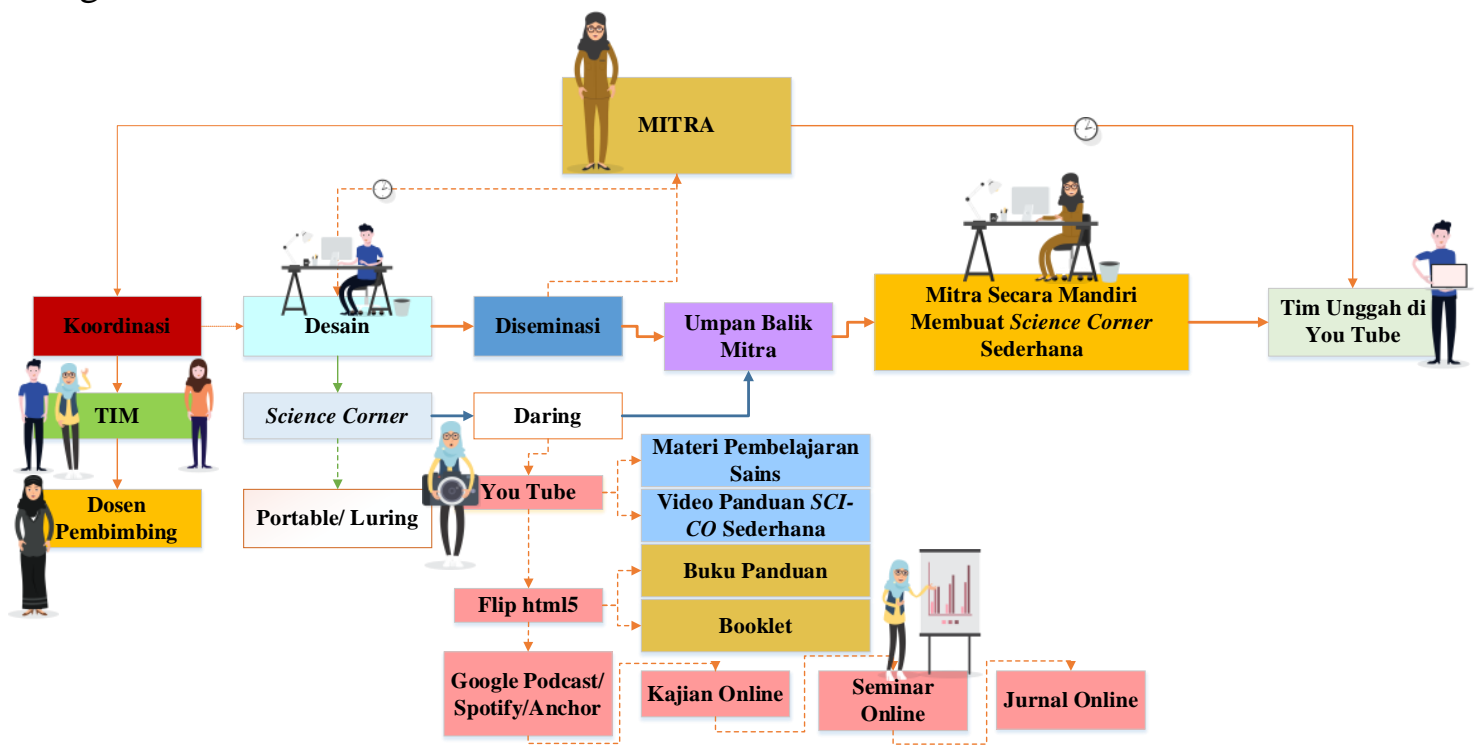

Gambar 1 Diagram Alir Pelaksanaan Pengabdian

Berdasarkan diagram alir di atas, berikut ini merupakan tahapan pelaksanaan pengabdian masyarakat yang telah terlaksana.

1. Penyuluhan

Penyuluhan kepada mitra dilakukan secara daring dengan berdasar pada permasalahan mitra akan kesulitan dalam membelajarkan sains di Taman KanakKanak. Proses ini dilakukan dengan mengetengahkan keberhasilan proses pembelajaran secara multi way dengan memanfaatkan audio dan visual sekaligus, 
sehingga jauh lebih interaktif. Tim juga melakukan introduksi kepada mitra mengenai Science Corner (Sci-Co) yang dapat direkomendasikan dalam membantu guru membelajarkan sains pada murid TK.

2. Desain

Media visual image ini akan mengarah kepada pembelajaran sains. Pemilihan materi sains dikarenakan murid dalam kesehariannya sering menjumpai fenomena alam yang secara otentik mudah diingat dan dipahaminya. Fenomena alam yang paling sering djumpai dan akan dikemas lebih menarik berbasis visual image adalah proses terjadinya hujan, proses terjadinya pelangi, dan beberapa proses lainnya. Pembuatan media visual image akan ditempatkan pada salah satu tempat yang disebut sebagai Sci-Co (Science Corner) atau pojok sains. Sci-Co merupakan tempat yang mudah diakses oleh murid untuk belajar mengenai proses-proses alam, sehingga akan merangsang proses berpikir murid untuk lebih kritis dan mampu analisis.

Desain dilaksanakan dengan memanfaatkan dan mengelaborasikan berbagai software untuk membantu merancang, membuat dan menghasilkan visualisasi rancangan sehingga akan lebih jelas mitra memahami rancangan yang dihadirkan. Proses rancangan tidak hanya menghasilkan gambar rancangan, tetapi mengedukasi mitra dalam melakukan proses pembelajaran menggunakan Sci-Co melalui buku panduan yang dibuat secara digital interaktif, video materi sains digital, booklet digital dan layout penempatan Sci-Co secara digital.

3. Diseminasi desain

Diseminasi merupakan suatu tahapan dimana hasil desain rancangan diberikan kepada mitra. Diseminasi ini berupa buku panduan, proses pembuatan dan video. Ketiga komponen tersebut dirancang secara digital untuk dapat diakses oleh mitra. Diseminasi hasil desain dilakukan secara daring dengan intensitas pertemuan dengan mitra hingga 4 kali termasuk perbaikan-perbaikan yang ditemui oleh mitra dalam memahami maupun mencoba mengaktualisasikan apa yang dijelaskan di dalam buku panduan untuk menjadi produk nyata. Proses diseminasi ini juga merupakan proses pendampingan kepada mitra dalam memahami desain Sci-Co hingga mitra mencoba untuk menghadirkan dan membuat Sc-Co di dalam kelas nantinya meskipun secara sederhana.

\section{HASIL DAN PEMBAHASAN}

Pelaksanaan PKM-M ini lebih memfokuskan kepada penciptaan desain atau rancangan Sci-Co serta panduan untuk memudahkan mitra mengenal Sci-Co atau mengaktualisasikan ke dalam ruang belajar murid. Tahapan dalam pelaksanaan pengabdian ini terdiri atas tiga tahapan yang dijabarkan sebagi hasil dari pelaksanaan kegiatan.

1. Penyuluhan

Penyuluhan merupakan suatu bentuk pendekatan kepada mitra sebelum dilakukan tahapan pelaksanaan inti. Idealnya sebuah program pengabdian dilakukan secara society parcipatory dimana mitra melakukan secara by doing agar mampu meningkatkan keterampilannya (Yasser dkk, 2020; Asfar dkk, 2019a). Akan tetapi, situasi pandemi Covid-19 berdampak interaksi antar tim dan mitra yakni Guru TK PGRI Keluarahan Palatte dilaksanakan secara daring.

Berdasarkan permasalahan mitra sekaitan dengan kurangnya alat bantu mengajarkan sains di TK menjadi salah satu urgensi masalah yang dihadapi mitra 
saat ini. Stimulus kemampuan dan pengembangan kognitif murid dimana pada level umur $<5$ tahun sangat membutuhkan rangsangan imajinasi dalam bentuk gambar dan warna bahkan suara. Jika hanya memaparkan sains dalam bentuk oral atau penjelasan guru, tentunya tidak berdampak besar bagi murid.

Mitra menginginkan adanya alat bantu berupa alat peraga yang lebih interaktif berupa audio dan visual. Oleh karena itu, tahapan penyuluhan merupakan kunci persuasif tim kepada mitra yaitu guru TK PGRI Kelurahan Palattae dalam mengintroduksi Sci-Co sebagai salah satu alternatif jawaban atau solusi kepada mitra dalam membelajarkan sains.

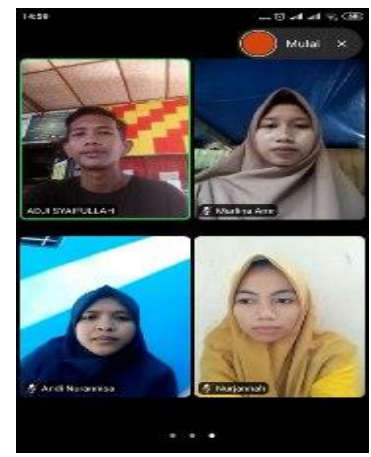

2. Desain

\section{Gambar 2 Penyuluhan Pada Mitra Secara Daring}

Tahapan desain merupakan hasil koordinasi tim dengan mitra mengenai Science-Corner (Sci-Co) yang akan dibangun/didesain. Beberapa spesifikasi alat yang dibutuhkan dalam rancangan ini dapat dilihat pada Tabel 1.

Tabel 1 Spesifikasi Alat

\begin{tabular}{|c|c|}
\hline $\begin{array}{c}\text { Perangkat } \\
\text { Keras }\end{array}$ & Spesifikasi dan Kegunaan \\
\hline Frame & $\begin{array}{l}\text { Frame digunakan sebagai penopang atau bingkai yang menambah estetika } \\
\text { Science Corner frame yang dapat digunakan (disarankan) berukuran } 50 \times 75 \\
\mathrm{~cm} \text { atau ukuran } 30 \times 40 \mathrm{~cm} \text { yang dapat dilihat dengan jelas secara visual. }\end{array}$ \\
\hline $\begin{array}{l}\text { Sketsa Visual } \\
\text { Image }\end{array}$ & $\begin{array}{l}\text { Sketsa disesuaikan dengan frame yaitu } 50 \times 75 \mathrm{~cm} \text { atau } 30 \times 40 \mathrm{~cm} \\
\text { berbahan flexy/albatros yang dapat ditembus oleh cahaya LED. }\end{array}$ \\
\hline Lampu LED & $\begin{array}{l}\text { LED dengan } 2 \text { watt berwarna warni yang digunakan sebagai efek } \\
\text { cahaya pada panah atau arah setiap topik sains. }\end{array}$ \\
\hline Speaker & $\begin{array}{l}\text { Speaker Bluetooth ini digunakan untuk menghubungkan audio dengan } \\
\text { perangkat gadget, handphone atau perangkat lainya sebagai sumber/pemutar } \\
\text { suara. Speaker ini dapat digunakan tanpa kabel atau menggunakan kabel } \\
(\text { Bluetooth). }\end{array}$ \\
\hline $\begin{array}{l}\text { Kabel } R C A(2 \\
\text { in 1) }\end{array}$ & $\begin{array}{l}\text { Kabel RCA 3,5 Male sebagai alternatif selain Bluetooth untuk } \\
\text { menghubungkan speaker dengan gadget atau gawai/handphone }\end{array}$ \\
\hline
\end{tabular}

Selain itu, perangkat lunak yang dibutuhkan dalam desain dapat dilihat pada Tabel 2 berikut. 
Vol. 1, No. 2, Desember 2020

Tabel 2 Spesifikasi Perangkat Lunak

\begin{tabular}{ll}
\hline $\begin{array}{c}\text { Perangkat } \\
\text { Lunak }\end{array}$ & \multicolumn{1}{c}{ Spesifikasi dan Kegunaan } \\
\hline Concept Draw & $\begin{array}{l}\text { Versi 13.01.1.305 (free) digunakan untuk membuat konsep alur } \\
\text { proses topik sains. }\end{array}$ \\
\hline 5D Planner & $\begin{array}{l}\text { Versi 4.3.11 (5039) (free) digunakan untuk membuat layout 5 } \\
\text { dimensi Science Corner. }\end{array}$ \\
\hline MS.Visio & $\begin{array}{l}\text { Ms.Visio 2016 digunakan untuk membuat konsep 2 dimensi konsep } \\
\text { pembelajaran sains dan beberapa gambar rancangan Science Corner. }\end{array}$ \\
\hline $\begin{array}{l}\text { Supermii } \\
\text { Animation }\end{array}$ & $\begin{array}{l}\text { Versi 3.9.8.7 (free) untuk digunakan membuat tokoh/karakter } \\
\text { animasi dalam pembuatan video setiap topik sains. }\end{array}$ \\
\hline Kinemaster & Versi 4.14.4.16740.GP (free) digunakan dalam pembuat editing video \\
& animasi. \\
\hline
\end{tabular}

Rancangan desain alat bantu Sci-Co diusahakan mampu diakses oleh perangkat handphone/gawai untuk memonitor audio dengan bantuan bluetooth. Sehingga, mitra mampu menggunakan alat Sci-Co kapan saja tanpa membutuhkan akses online/daring (penggunaan data internet). Meskipun demikian, tim pelaksana untuk menjawab perkembangan pesatnya penggunaan daring dalam belajar, tim membuat Buku Panduan yang dapat diakses secara daring, Booklet mengenai topik pembelajaan sains yang dapat pula diakses secara daring, dan kedua item ini dapat pula diakses dengan buku digital interaktif yang jauh lebih menarik.

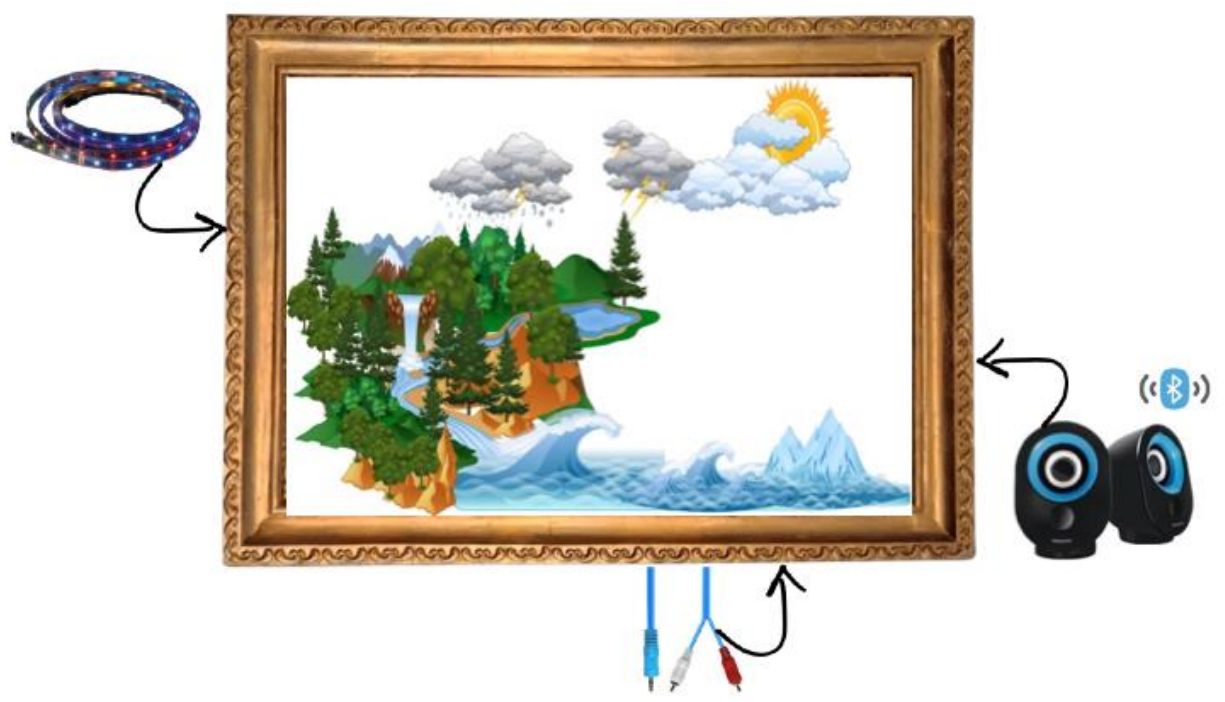

Gambar 3 Rancangan Desain Alat

3. Diseminasi desain

Diseminasi hasil rancangan dilakukan secara daring kepada mitra. Hasil desain diberikan kepada mitra dalam bentuk Buku Panduan Digital. Buku Panduan Digital akan memudahkan mitra dalam mengenal atau mengaktualisasikan Sci-Co dengan menggunakan barang-barang bekas yang tak terpakai mendekati Sci-Co sebenarnya secara desain. Proses diseminasi dengan mitra akan menjadi proses lanjutan setelah 
mitra membaca buku panduan, jika mitra menemukan sesuatu yang belum dipahami, maka Tim Pelaksana akan menjelaskan secara detail kepada mitra hal yang belum diketahuinya. Tim Juga memaparkan kepada mitra akan kemampuan pengembangan Sci-Co untuk dibuat dengan lebih mudah oleh mitra mendekati desain Sci-Co atau menghadirkan Sci-Co dalam bentuk full digital.

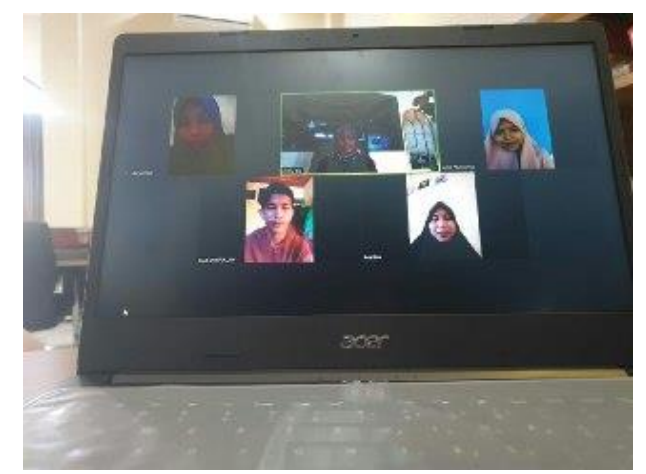

Gambar 4 Diseminasi Desain Kepada Mitra

Antusiasme mitra cukup besar untuk mengetahui dan mengaktualisasikan Sci-Co ke dalam ruang area kelas murid TK untuk lebih memudahkan dan murid lebih mampu menyerap penyampain pesan yang disampaikan oleh guru secara kontekstual. Makna konstekstual dalam hal ini yaitu guru membelajarkan sains kepada murid dengan mengetengahkan kejadian-kejadian yang sering dijumpai oleh murid, sehingga murid secara tidak langsung dapat menstimulus kemampuan high order thinking yang dimilikinya untuk jauh lebih mengenal alam atau fenomena alam yang terjadi di lingkungan sekitarnya dan dampaknya pembelajaran akan lebih bermakna (meaningfull learning) (Asfar dkk, 2019c). Pada saat ini, diharapkan guru mampu lebih kreatif dan inovatif sehingga mampu membawa murid mengonstruksi pengetahuannya dan mampu membuat murid paham akan konsep atau topik yang diajarkannya (Asfar dkk, 2019b).

Pada penerapan hasil diseminasi, secara tidak langsung, mitra dalam hal ini guru mampu mengikuti panduan dan mampu memiliki keterampilan baru menciptakan perangkat alat peraga baru yang lebih interaktif hanya dalam waktu \pm 1 minggu setelah diseminasi dilakukan. Menurut guru, biasanya untuk menjelaskan sains dikelas sekitar \pm 1 jam lebih, menggunakan Sci-Co diklaim oleh guru akan lebih mudah dimana guru hanya mengarahkan dan menyimpulkan topik yang telah dibahas.

\section{KESIMPULAN}

Hasil pengabdian dalam bentuk PKM-M ini dapat disimpulkan bahwa Sci-Co dapat menjadi satu bentuk media bantu bagi guru TK dalam membelajarkan sains bagi mu rid TK. Dalam pelaksanaan skema ini dilakukan pula rancangan Sci-Co berupa desain SciCo, Buku Panduan, dan Booklet yang dapat diakses secara daring. Keberlanjutan dari desain atau rancangan Sci-Co akan memberikan kegiatan baru bagi guru dan murid membelajarkan dan mempelajari sains dengan stimulisasi kognitif yang akan membangun high order thinking murid.

\section{UCAPAN TERIMA KASIH}

Terima kasih kepada Dirjen Belmawa Kemndikbud atas pendanaan dalam skema PKM-M ini dan STKIP Muhammadiyah Bone. 


\section{DAFTAR PUSTAKA}

Abidah, K., Laksmiwati, A.A., Sasfiranti, Y., Supradewi, R., 2019. Pengaruh Penggunaan Warna terhadap Short Term Memory untuk Peningkatan Pemahaman Matematika. PSISULA: Prosiding Berkala Psikologi, 1(1), 96-103.

Asfar, A.M.I.A., Arifuddin, W., Rahman, A. 2019a. Pengolahan Kayu Sepang di Desa Biru Kecamatan Kahu Kabupaten Bone. Jurnal Panrita Abdi, 3(2), 97-104. DOI: 10.13140/RG.2.2.19814.16961

Asfar, AMIT., Asmawaty., Nursyam, A. 2019b. Mathmatical Concept Understanding: The Impact of Intergrated Learning Model. Al-Jabar: Jurnal Pendidikan Matematika, 10(2), 211-222.

Asfar., AMIT., Asfar, AMIA., Asfar, A.H., Sirwanti., Rianti, M., Kurnia, A. 2019c. The Elaboration Study As an Innovative Learning Model in Effort to Improve the Understanding of Mathematics. International Journal of Innovation, Creativity and Change, 5(3), 842-847.

Azis, E., Asfar, AMIT., Hasanuddin., Asfar, AMIA., Nur, A.S.A. 2019. Analysis of Validity and Practicality of ROAR (Read, Observe, Auditory, Review) Learning Model. ICONSS Proceeding Series: The $2^{\text {nd }}$ International Conference on Natural \& Social Sciences (ICONSS 2019), Palopo, 398-404.

Hartoyo. 2009. Penerapan Model Pembelajaran Kontekstual Berbasis Kompetensi untuk Meningkatkan Efektivitas Pembelajaran. Jurnal Kependidikan, 1(1), 98-106.

Mahnu, N. 2012. Media Pembelajaran (Kajian terhadap Langkah-langkah Pemilihan Media dan Implementasinya dalam Pembelajaran). Jurnal Pemikiran Islam, 37(1), 27-33.

Musrikah, 2018. Higher Order Thingking Skill (HOTS) untuk Anak Sekolah Dasar dalam Pembelajaran Matematika. Jurnal Perempuan dan Anak, 2(2),340-360.

Roza, M.M., 2012. Pelaksanaan Pembelajaran Sains Anak Taman Kanak-Kanak Aisyiyah Bustanul Athfal 29 Padang. Jurnal Ilmiah PG-PAUD, 1(1), 2-11.

Saepudin, A. 2011. Pembelajaran Sains pada Program Pendidikan Anak Usia Dini. Jurnal Teknodik, 15(2), 213-226).

Sujarwo, S., Oktaviana, R. 2017. Pengaruh Warna terhadap Short Term Memory pada Siswa Kelas VIII SMP N 37 Palembang. PSIKIS-Jurnal Psikologi Islami, 3(1), 3342.

Sulastri, A. 2016. Penerapan Pendekatan Kontekstual dalam Pembelajaran Matematika untuk Meningkatkan Pemahaman Konsep Matematis Siswa Sekolah Dasar. Jurnal Pendidikan Guru Sekolah Dasar, 1(1), 156-170.

Sutama, I.M., Gonadi, L., Astuti, W., Anisa, N. 2020. Pengembangan Aktivitas Bermain Pemicu Kecakapan Berpikir Tingkat Tinggi Anak Bagi Guru TK Kecamatan Klojen Kota Malang. Jurnal Graha Pengabdian, 2(1), 27-39.

Tafonao, T. 2018. Peranan Media Pembelajaran dalam Meningkatkan Minat Belajar Mahasiswa. Jurnal Komunikasi Pendidikan, 2(2), 103-113.

Yasser, M. Asfar, AMIA., Asfar, AMIT., Rianti, Marlia., Budianto, Eko. 2020. Pengembangan Produk Olahan Gula Merah Tebu dengan Pemanfaatan Ekstrak Herbal di Desa Latellang Kabupaten Bone. Jurnal Panrita Abdi, 4(1), 42-51. 